\title{
Kinetics and Mechanism of the Pyridinolyses of Dimethyl Phosphinic and Thiophosphinic Chlorides in Acetonitrile
}

\author{
Nilay Kumar Dey, Keshab Kumar Adhikary, Chan Kyung Kim,* and Hai Whang Lee* \\ Department of Chemistry, Inha University, Incheon 402-751, Korea. *E-mail: hwlee@inha.ac.kr \\ Received October 5, 2010, Accepted October 18, 2010
}

Key Words: Biphasic concave upward free energy relationship, Phosphoryl transfer reaction, Pyridinolysis, Dimethyl phosphinic and thiophosphinic chlorides, Isokinetic relationship

Continuing the studies on phosphoryl transfer reactions, ${ }^{1}$ the reactions of dimethyl phosphinic $\left[\mathrm{Me}_{2} \mathrm{P}(=\mathrm{O}) \mathrm{Cl} ; 1 \mathrm{OO}\right]$ and thiophosphinic $\left[\mathrm{Me}_{2} \mathrm{P}(=\mathrm{S}) \mathrm{Cl}\right.$; $\left.1 \mathrm{~S}\right]$ chlorides with substituted $(\mathrm{X})$ pyridines are investigated kinetically in acetonitrile $(\mathrm{MeCN})$ at -25.0 and $35.0^{\circ} \mathrm{C}$, respectively (eq 1) to clarify the phosphoryl transfer mechanism, as well as to compare the pyridinolyses of diphenyl phosphinic $\left[\mathrm{Ph}_{2} \mathrm{P}(=\mathrm{O}) \mathrm{Cl} ; 2 \mathrm{O}\right]$ and thiophosphinic $\left[\mathrm{Ph}_{2} \mathrm{P}(=\mathrm{S}) \mathrm{Cl} ; 2 \mathrm{~S}\right]$ chlorides. $^{1 \mathrm{~d}}$

$$
\begin{gathered}
\mathrm{Me}_{2} \mathrm{P}(=\mathrm{L}) \mathrm{Cl}+\mathrm{XC}_{5} \mathrm{H}_{4} \mathrm{~N} \stackrel{\mathrm{MeCN}}{\longrightarrow} \mathrm{Me}_{2} \mathrm{P}(=\mathrm{L}) \mathrm{NC}_{5} \mathrm{H}_{4} \mathrm{X}+\mathrm{Cl}^{-} \\
\mathrm{L}=\mathrm{O}(\mathbf{1 O}) \text { at }-25.0^{\circ} \mathrm{C} \text { and } \mathrm{L}=\mathrm{S}(\mathbf{1 S}) \text { at } 35.0^{\circ} \mathrm{C} \\
\mathrm{X}=\text { 4-MeO, 4-Me, 3-Me, } \mathrm{H}, 3-\mathrm{Ph}, 3-\mathrm{MeO}, 3-\mathrm{Cl}, \\
\text { 3-Ac, 4-Ac, 3-CN, and 4-CN }
\end{gathered}
$$

The observed pseudo-first-order rate constants $\left(k_{\text {obsd }}\right)$ were found to follow eq 2 for all of the reactions under pseudo-firstorder conditions with a large excess of pyridine nucleophile.

$$
k_{\mathrm{obsd}}=k_{0}+k_{2}\left[\mathrm{XC}_{5} \mathrm{H}_{4} \mathrm{~N}\right]
$$

The $k_{0}$ values were negligible $\left(k_{0}=0\right)$ in $\mathrm{MeCN}$. The second-order rate constants $\left(k_{2}\right)$ were determined for at least five concentrations of X-pyridines. The linear plots of eq 2 suggest that there is no base-catalysis or noticeable side reactions and that the overall reaction is described by eq 1 . The $k_{2}$ values and the selectivity parameters ( $\rho_{\mathrm{X}}$ and $\beta_{\mathrm{X}}$ ) are summarized in Table 1. The pyridinolysis rates of $\mathbf{1 0}$ are surprisingly faster than those of $1 \mathrm{~S}$ (note the reaction temperature and order of magnitude of second-order rate constant: $-25.0{ }^{\circ} \mathrm{C}$ and $+35.0{ }^{\circ} \mathrm{C} ; 10^{1}$ and $10^{-4}$ for $\mathbf{1 O}$ and $\mathbf{1 S}$, respectively). The substituent effects of the nucleophiles upon the pyridinolysis rates of $\mathbf{1 S}$ correlate with those for a typical nucleophilic substitution reaction, whereby a stronger nucleophile results in a faster rate. However, those of $\mathbf{1 0}$ are not consistent with a typical one, in which unusual minimum rate is obtained at 3-methoxy pyridine. As a result, both negative $\rho_{\mathrm{X}}(=-0.87)$ and positive $\rho_{\mathrm{X}}(=+0.16)$ values are observed for strongly and weakly basic pyridines, respectively. The Brönsted $\beta_{\mathrm{X}}$ values were obtained by correlating $\log k_{2}$ $(\mathrm{MeCN})$ with $\mathrm{p} K_{\mathrm{a}}\left(\mathrm{H}_{2} \mathrm{O}\right)$, which was justified theoretically and experimentally. $^{2}$

As seen in Figure 3 (and Table 1), the pyridinolysis $\left(\mathrm{C}_{5} \mathrm{H}_{5} \mathrm{~N}\right.$ ) rate constant of the $\mathrm{P}=\mathrm{O}$ system is greater than that of its $\mathrm{P}=\mathrm{S}$ counterpart: $k_{2}(\mathbf{1 O}) / k_{2}(\mathbf{1 S})=10.2 \times 10^{1} / 7.44 \times 10^{-4}=137,000$
Table 1. Second-order rate constants $\left(k_{2} / \mathrm{M}^{-1} \mathrm{~s}^{-1}\right)$ and selectivity parameters $^{a}$ ( $\rho_{\mathrm{X}}$ and $\beta_{\mathrm{X}}$ ) for the reactions of dimethyl phosphinic (10) and thiophosphinic (1S) chlorides with $\mathrm{XC}_{5} \mathrm{H}_{4} \mathrm{~N}$ in $\mathrm{MeCN}$ at -25.0 and $35.0^{\circ} \mathrm{C}$, respectively

\begin{tabular}{ccc}
\hline $\mathrm{X}$ & $\begin{array}{c}k_{2} \times 10^{-1}\left(-25.0{ }^{\circ} \mathrm{C}\right) \\
\mathbf{1 0}\left[\mathrm{Me}_{2} \mathrm{P}(=\mathrm{O}) \mathrm{Cl}\right]\end{array}$ & $\begin{array}{c}k_{2} \times 10^{4}\left(35.0^{\circ} \mathrm{C}\right) \\
\mathbf{1 S}\left[\mathrm{Me}_{2} \mathrm{P}(=\mathrm{S}) \mathrm{Cl}\right]\end{array}$ \\
\hline $4-\mathrm{MeO}$ & $5.89 \pm 0.17$ & $172 \pm 4$ \\
$4-\mathrm{Me}$ & $4.85 \pm 0.10$ & $50.6 \pm 1.2$ \\
$3-\mathrm{Me}$ & $4.05 \pm 0.12$ & $18.8 \pm 0.2$ \\
$\mathrm{H}$ & $3.43 \pm 0.04$ & $7.44 \pm 0.14$ \\
$3-\mathrm{Ph}$ & $3.03 \pm 0.09$ & $6.13 \pm 0.13$ \\
$3-\mathrm{MeO}$ & $2.79 \pm 0.03$ & $4.77 \pm 0.14$ \\
$3-\mathrm{Cl}$ & $3.06 \pm 0.03$ & $1.98 \pm 0.01$ \\
$3-\mathrm{Ac}$ & $3.08 \pm 0.05$ & $1.91 \pm 0.01$ \\
$4-\mathrm{Ac}$ & $3.22 \pm 0.07$ & $1.07 \pm 0.02$ \\
$3-\mathrm{CN}$ & $3.31 \pm 0.09$ & $0.797 \pm 0.022$ \\
$4-\mathrm{CN}$ & $3.44 \pm 0.10$ & $0.734 \pm 0.012$ \\
$\rho_{\mathrm{X}}$ & $-0.87 \pm 0.02(\mathrm{r}=0.999)^{b}$ & $-4.96 \pm 0.18(\mathrm{r}=0.999)^{d}$ \\
& $+0.16 \pm 0.01(\mathrm{r}=0.988)^{c}$ & $-1.62 \pm 0.06(\mathrm{r}=0.995)^{e}$ \\
$\beta_{\mathrm{X}}$ & $+0.17 \pm 0.01(\mathrm{r}=0.999)^{b}$ & $+0.97 \pm 0.01(\mathrm{r}=0.999)^{d}$ \\
& $-0.03 \pm 0.01(\mathrm{r}=0.989)^{c}$ & $+0.27 \pm 0.02(\mathrm{r}=0.990)^{e}$ \\
\hline
\end{tabular}

${ }^{a}$ The $\sigma$ values were taken from Hansch, C.; Leo, A.; Taft, R. W. Chem. Rev. 1991, 91, 165. The $\mathrm{p} K_{\mathrm{a}}$ values were taken from (i) Fischer, A.; Galloway, W. J.; Vaughan, J. J. Chem. Soc. 1964, 3591; (ii) Dean, J. A. Handbook of Organic Chemistry; McGraw-Hill: New York, 1987; Chapter 8. ${ }^{b} \mathrm{For} \mathrm{X}=4-\mathrm{MeO}, 4-\mathrm{Me}, 3-\mathrm{Me}, \mathrm{H}$, and 3-Ph. ${ }^{c} \mathrm{For} \mathrm{X}=3-\mathrm{MeO}$, 3-Cl, 3-Ac, 4-Ac, 3-CN, and 4-CN. ${ }^{d}$ For $\mathrm{X}=4-\mathrm{MeO}, 4-\mathrm{Me}, 3-\mathrm{Me}$, and $\mathrm{H} .{ }^{e} \mathrm{For} \mathrm{X}=$ $\mathrm{H}, 3-\mathrm{Ph}, 3-\mathrm{MeO}, 3-\mathrm{Cl}, 3-\mathrm{Ac}, 4-\mathrm{Ac}, 3-\mathrm{CN}$, and 4-CN.
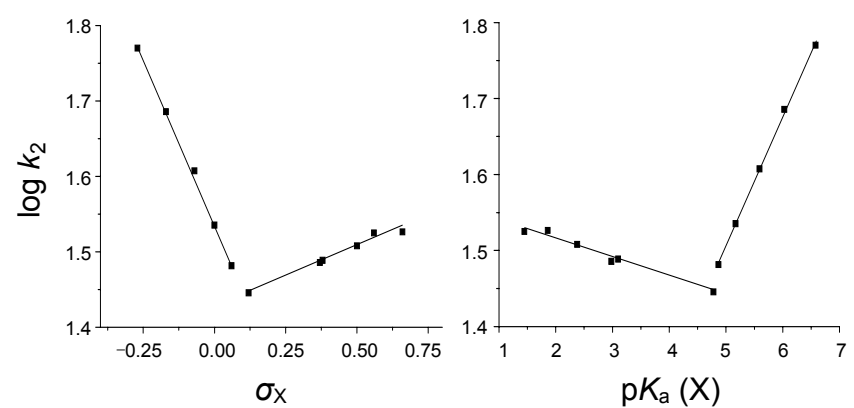

Figure 1. The Hammett $\left(\log k_{2}\right.$ vs $\left.\sigma_{\mathrm{X}}\right)$ and Brönsted $\left[\log k_{2} v s \mathrm{p} K_{\mathrm{a}}(\mathrm{X})\right]$ plots of the reactions of $10\left[\mathrm{Me}_{2} \mathrm{P}(=\mathrm{O}) \mathrm{Cl}\right]$ with X-pyridines in $\mathrm{MeCN}$ at $-25.0{ }^{\circ} \mathrm{C}$. 

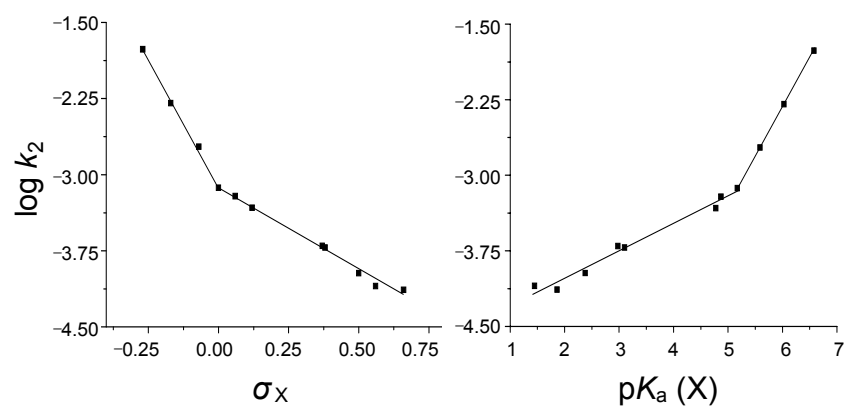

Figure 2. The Hammett $\left(\log k_{2} v s \sigma_{\mathrm{X}}\right)$ and Brönsted $\left[\log k_{2} v s \mathrm{p} K_{\mathrm{a}}(\mathrm{X})\right]$ plots of the reactions of $\mathbf{1 S}\left[\mathrm{Me}_{2} \mathrm{P}(=\mathrm{S}) \mathrm{Cl}\right]$ with X-pyridines in $\mathrm{MeCN}$ at $35.0{ }^{\circ} \mathrm{C}$.

and $k_{2}(\mathbf{2 O}) / k_{2}(\mathbf{2 S})=30 .{ }^{1 \mathrm{~d}}$ Herein, the second-order rate constant, $k_{2}=10.2 \times 10^{1} \mathrm{M}^{-1} \mathrm{~s}^{-1}$, at $35.0{ }^{\circ} \mathrm{C}$ for the reactions of $\mathbf{1 0}$ with unsubstituted pyridine was obtained by extrapolation in the Arrhenius plot with the empirical kinetic data $(\mathrm{r}=0.984): k_{2}=$ $3.43\left(-25.0^{\circ} \mathrm{C}\right), 4.04\left(-15.0^{\circ} \mathrm{C}\right)$, and $5.39 \times 10^{1} \mathrm{M}^{-1} \mathrm{~s}^{-1}\left(-5.0^{\circ} \mathrm{C}\right)$. It is well known that the $\mathrm{P}=\mathrm{O}$ systems are generally more reactive than their $\mathrm{P}=\mathrm{S}$ counterparts for several reasons, the socalled "thio effect", which is mainly the electronegativity difference between $\mathrm{O}$ and $\mathrm{S}$ and favors $\mathrm{O}$ over $\mathrm{S}{ }^{3}$ The natural bond order (NBO) charges [B3LYP/6-311+G(d,p) level of theory] $]^{4}$ of the reaction center $P$ in the gas phase are $1.793(\mathbf{1 0})$, $1 \mathrm{~m}$ $1.180(\mathbf{1 S}),{ }^{1 \mathrm{~m}} 1.844(\mathbf{2 O}),{ }^{11}$ and $1.236(\mathbf{2 S}),{ }^{1 \mathrm{~d}}$ which are consistent with the inductive effects of $\mathrm{Ph}\left(\sigma_{\mathrm{I}}=+0.12\right)$ and $\mathrm{Me}\left(\sigma_{\mathrm{I}}=\right.$ $-0.01)$ ligands. ${ }^{5}$ The $\mathrm{NBO}$ charges on the $\mathrm{P}$ atom of $\mathrm{P}=\mathrm{O}$ systems are greater $(c a .0 .6)$ than those of their $\mathrm{P}=\mathrm{S}$ counterparts, implying the electronegativity difference between $\mathrm{O}$ and $\mathrm{S}$.

Solely considering the positive charge of the reaction center
$\mathrm{P}$ atom (or the electronic influence of the two ligands), the pyridinolysis $\left(\mathrm{C}_{5} \mathrm{H}_{5} \mathrm{~N}\right)$ rate of $\mathbf{1 O}$ (and $\mathbf{1 S}$ ) should be slower than that of 20 (and 2S), i.e., $k_{2}(\mathbf{1 O}) / k_{2}(\mathbf{2 O})<1$ [and $k_{2}(\mathbf{1 S}) / k_{2}(\mathbf{2 S})<1$ ]. However, the observed rate ratio of $k_{2}(\mathbf{1 0}) / k_{2}(\mathbf{2 O})=1,870$ is completely opposite to expectations from the inductive effects of the ligands. At a glance, the rate ratio of $k_{2}(\mathbf{1 S}) / k_{2}(\mathbf{2 S})=0.41$ seems to be consistent with expectations from the inductive effects of the ligands. The sequence of $\sum \sigma_{\mathrm{I}}$ of the two ligands is $-0.02\left(\mathrm{Me}_{2}: 10\right.$ and $\left.\mathbf{1 S}\right)<0.24\left(\mathrm{Ph}_{2}: 20\right.$ and $\left.2 \mathrm{~S}\right)<0.52$ $[(\mathrm{PhO}) \mathrm{Ph}]<0.56\left[(\mathrm{EtO})_{2}\right]<0.60\left[(\mathrm{MeO})_{2}\right]<0.80\left[(\mathrm{PhO})_{2}\right]{ }^{5}$ However the sequence of the second-order rate constants of the pyridinolyses $\left(\mathrm{C}_{5} \mathrm{H}_{5} \mathrm{~N}\right)$ of $\mathrm{P}=\mathrm{O}$ and $\mathrm{P}=\mathrm{S}$ systems in $\mathrm{MeCN}$ at $35.0{ }^{\circ} \mathrm{C}$ is as follows: $k_{2} \times 10^{3} \mathrm{M}^{-1} \mathrm{~s}^{-1}=102,000$ [10: $\mathrm{Me}_{2} \mathrm{P}$ $(=\mathrm{O}) \mathrm{Cl}]<266\left[(\mathrm{PhO})_{2} \mathrm{P}(=\mathrm{O}) \mathrm{Cl}\right]^{1 \mathrm{a}}<64.7\left[(\mathrm{MeO}){ }_{2} \mathrm{P}(=\mathrm{O}) \mathrm{Cl}\right]^{1 \mathrm{~g}}<$ 54.6 [2O: $\left.\mathrm{Ph}_{2} \mathrm{P}(=\mathrm{O}) \mathrm{Cl}\right]^{1 \mathrm{~d}}<52.8\left[(\mathrm{EtO})_{2} \mathrm{P}(=\mathrm{O}) \mathrm{Cl}\right] ;^{\text {lg }}$ and 0.744 11S: $\left.\mathrm{Me}_{2} \mathrm{P}(=\mathrm{S}) \mathrm{Cl}\right]<1.19\left[(\mathrm{EtO})_{2} \mathrm{P}(=\mathrm{S}) \mathrm{Cl}\right]^{1 \mathrm{~g}}<1.54\left[(\mathrm{MeO})_{2} \mathrm{P}\right.$ $(=\mathrm{S}) \mathrm{Cl}]^{1 \mathrm{~g}}<1.83\left[2 \mathrm{~S}: \mathrm{Ph}_{2} \mathrm{P}(=\mathrm{S}) \mathrm{Cl}\right]^{1 \mathrm{~d}}<11.4[(\mathrm{PhO}) \mathrm{PhP}(=\mathrm{S}) \mathrm{Cl}] .{ }^{1 \mathrm{f}}$ There is no linear correlation between $\sum \sigma_{\mathrm{I}}$ and $k_{2}$ for both $\mathrm{P}=\mathrm{O}$ and $\mathrm{P}=\mathrm{S}$ systems. Regarding to the anilinolysis $\left(\mathrm{C}_{6} \mathrm{H}_{5} \mathrm{NH}_{2}\right)$ in $\mathrm{MeCN}$ at $55.0^{\circ} \mathrm{C}$, the rate ratios of $k_{2}(\mathbf{1 O}) / k_{2}(\mathbf{2 O})=4,520^{11, \mathrm{q}}$ and $k_{2}(\mathbf{1 S}) / k_{2}(\mathbf{2 S})=16^{1 \mathrm{~m}, \mathrm{r}}$ were also contrary to expectations for the electronic influence of the two ligands. It should be noted that the electrophilicity of the substrate is the major factor to determine the reactivity of the phosphoryl transfer reaction as can be seen in "thio effect", i.e., $\mathrm{P}=\mathrm{O}$ system has a greater reactivity compared to its $\mathrm{P}=\mathrm{S}$ counterpart. However, the electronic influence of the two ligands on the aminolysis rate is no more major factor within each reaction system, $\mathrm{P}=\mathrm{O}$ or $\mathrm{P}=\mathrm{S}$.

The authors reported that the degree of steric hindrance of the two ligands is the major factor to determine the anilinolysis rates of both the $\mathrm{P}=\mathrm{O}$ and $\mathrm{P}=\mathrm{S}$ systems in $\mathrm{MeCN} .{ }^{11-\mathrm{t}}$ However, the sequence of the pyridinolysis rates of both the $\mathrm{P}=\mathrm{O}$ and

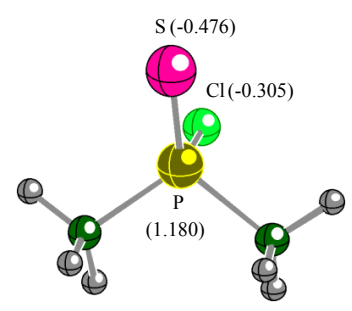

(1S)

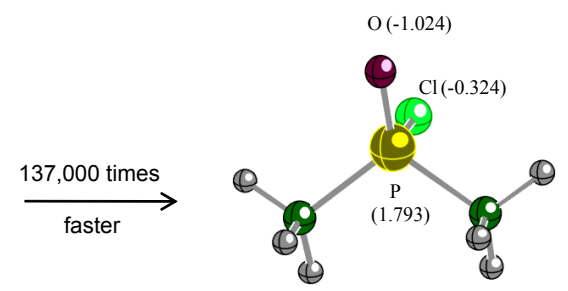

(10)

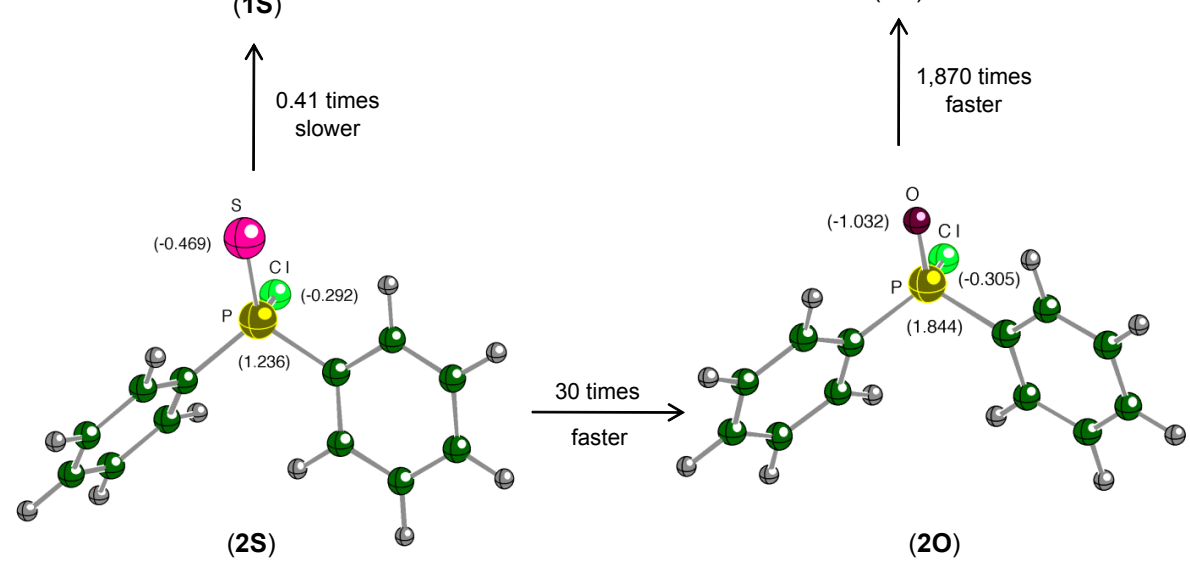

Figure 3. The B3LYP/6-311+G(d,p) geometries and NBO charges of $\mathbf{1 0}, \mathbf{1 S}, \mathbf{2 0},{ }^{\text {ld }}$ and $\mathbf{2} \mathrm{S}^{1 \mathrm{~d}}$ in the gas phase. The pyridinolysis $\left(\mathrm{C}_{5} \mathrm{H}_{5} \mathrm{~N}\right)$ rate ratios in acetonitrile at $35.0{ }^{\circ} \mathrm{C}$ are displayed next to the arrows. 
$\mathrm{P}=\mathrm{S}$ systems is not linearly correlated with the summations of steric parameters $\left(E_{\mathrm{S}}\right)$ of the two ligands; $\sum E_{\mathrm{S}}=0.00\left(\mathrm{Me}_{2}: 10\right.$ and 1S $)<4.43\left[(\mathrm{MeO})_{2}\right]<4.67\left[(\mathrm{EtO})_{2}\right]<4.96\left(\mathrm{Ph}_{2}: 20\right.$ and 2S $)<5.11[(\mathrm{PhO}) \mathrm{Ph}]<5.35\left[(\mathrm{PhO})_{2}\right] .{ }^{6}$ Thus, it is evident that neither the electronic influence nor the degree of steric hindrance of the two ligands is not the major factor to determine the pyridinolysis rates of both the $\mathrm{P}=\mathrm{O}$ and $\mathrm{P}=\mathrm{S}$ systems.

As seen in Figs. 1-2, the Hammett and Brönsted plots for substituent $\mathrm{X}$ variations for the pyridinolyses of $\mathbf{1 0}$ (with a break region between 3-phenyl and 3-MeO pyridines) and $\mathbf{1 S}$ (with a break point at pyridine) exhibit biphasic concave upwards, as observed in the pyridinolyses of aryl phenyl isothiocyanophosphates $\left[\left(\mathrm{YC}_{6} \mathrm{H}_{4} \mathrm{O}\right)(\mathrm{PhO}) \mathrm{P}(=\mathrm{O}) \mathrm{NCS}\right],{ }^{1 \mathrm{c}} \mathbf{2 S},{ }^{1 \mathrm{~d}}$ dimethyl $\left[(\mathrm{MeO})_{2}\right.$ $\mathrm{P}(=\mathrm{S}) \mathrm{Cl}]{ }^{1 \mathrm{~g}}$ and diethyl $\left[(\mathrm{EtO})_{2} \mathrm{P}(=\mathrm{S}) \mathrm{Cl}\right]^{1 \mathrm{~g}}$ chlorothionophosphates in $\mathrm{MeCN}$. Biphasic concave upward Hammett plots for substituent $Z$ (substituent in the leaving group) variations were also observed for the pyridinolyses of $Z-N$-aryl- $P, P$-diphenyl phosphinic amides $\left[\mathrm{Ph}_{2} \mathrm{P}(=\mathrm{O}) \mathrm{NHPhZ}\right]$ in DMSO. ${ }^{\text {lh }}$ Herein, the magnitudes of $\rho_{\mathrm{X}}$ and $\beta_{\mathrm{X}}$ of strongly basic pyridines are greater than those of weakly basic pyridines, and those of $1 \mathrm{~S}$ are greater than those of $\mathbf{1 0}$

The authors propose concerted mechanism for the pyridinolyses of both $\mathbf{1 O}$ and $\mathbf{1 S}$ on the basis of the same reason as discussed earlier for the pyridinolyses of aryl phenyl isothiocyanophosphates, ${ }^{\text {lc }}$ diphenyl thiophosphinic chloride, ${ }^{\text {ld }}$ dimethyl, ${ }^{1 \mathrm{~g}}$ and diethyl ${ }^{1 \mathrm{~g}}$ chlorothionophosphates. Biphasic concave upward free energy relationships for substituent $X$ variations were rationalized by a change of nucleophilic attacking direction from a dominant backside [apical position in the trigonal bipyramidal pentacoordinate (TBP-5C) transition state (TS) I] towards the $\mathrm{Cl}$ leaving group for weakly basic pyridines to a dominant frontside (equatorial position in the TBP-5C TS II) for strongly basic pyridines, in which the pyridine and $\mathrm{Cl}$ occupy adjacent spaces in the TS. ${ }^{1 \mathrm{c}, \mathrm{d}, \mathrm{g}}$

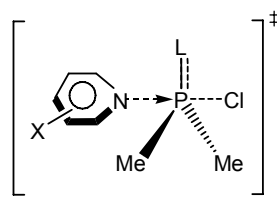

TS I

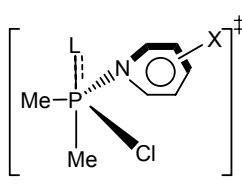

TS II
The unusual positive $\rho_{\mathrm{X}}(=+0.16)$ and negative $\beta_{\mathrm{X}}(=-0.03)$ values of 10 (Table 1 and Fig. 1) for the weakly basic pyridines ( $\mathrm{X}=3-\mathrm{MeO}, 3-\mathrm{Cl}, 3-\mathrm{Ac}, 4-\mathrm{Ac}, 3-\mathrm{CN}$, and 4-CN) can be occurred because of (i) desolvation of ground state, (ii) TS imbalance, or (iii) isokinetic relationship.

(i) The discrete linear free energy relationships are reported because of a desolvation step prior to the rate-limiting nucleophilic attack with a smaller value of $\beta_{\mathrm{X}}$ when the nucleophile is anion and the solvent is polar protic, e.g., water. ${ }^{7}$ However, in the present work, the positive $\rho_{\mathrm{X}}$ (and negative $\beta_{\mathrm{X}}$ ) value for the less basic pyridines are not ascribed to a desolvation step prior to the rate-limiting nucleophilic attack, since the pyridine nucleophile is neutral and the $\mathrm{MeCN}$ solvent is dipolar aprotic.

(ii) The authors reported that the sign of $\rho_{\mathrm{X}}$ changes from positive for the relatively strong electron-donating Y substituents to negative for the more electron-withdrawing substituents of the reactions of 1-(Y-phenyl) ethyl chlorides with X-anilines in methanol. ${ }^{8}$ The anilinolyses of Y-benzhydryl chlorides in $\mathrm{MeOH}-\mathrm{MeCN}$ also exhibited the change of the sign of $\rho_{\mathrm{X}}$ depending on Y substituents. ${ }^{9}$ The positive $\rho_{\mathrm{X}}$ values were interpreted in terms of a TS structure in which nearly complete bond formation between the nucleophile and cation formed in an ionpair pre-equilibrium is coupled with a TS imbalance phenomenon, advocated by Jencks ${ }^{10}$ and Bernasconi. ${ }^{11}$ However, the positive $\rho_{\mathrm{X}}$ value of $\mathbf{1 0}$ is inadequate to a TS imbalance phenomenon, since it only occurs in electron-withdrawing X substituents and $\mathrm{P}=\mathrm{O}$ system.

(iii) For a large number of reaction series, it is found that $\delta \Delta H^{\ddagger}$ and $\delta \Delta S^{\ddagger}$ are proportional. ${ }^{12}$ The observed second-order rate constants of 10 with 3-methoxy, 4-acetyl, and 4-cyano pyridines are $1.30,1.01,0.835 \times 10^{2} \mathrm{M}^{-1} \mathrm{~s}^{-1}$ at $-20.0^{\circ} \mathrm{C}$ and 2.26 , $1.56,1.43 \times 10^{2} \mathrm{M}^{-1} \mathrm{~s}^{-1}$ at $-15.0^{\circ} \mathrm{C}$, respectively. It should be noted that the sequence of the pyridinolysis rate is changed from $3-\mathrm{MeO}<4-\mathrm{Ac}<4-\mathrm{CN}$ with $\rho_{\mathrm{X}}=+0.16$ at $-25.0{ }^{\circ} \mathrm{C}$ via $3-\mathrm{MeO}>$ $4-\mathrm{Ac}>4-\mathrm{CN}$ with $\rho_{\mathrm{X}}=-0.34$ at $-20.0{ }^{\circ} \mathrm{C}$ to $3-\mathrm{MeO}>4-\mathrm{Ac}>$ 4-CN with $\rho_{\mathrm{X}}=-0.38$ at $-15.0{ }^{\circ} \mathrm{C}$ as shown in Fig. 4 . The isokinetic temperature according to eq 3 is $T_{\text {ISOKINETIC }}=249.4^{\circ} \mathrm{K}=$ $-23.8^{\circ} \mathrm{C}$ (Fig. 5), based on $\Delta H^{\neq}=26.2$ and $\Delta S^{\neq}=-54$ for $\mathrm{X}=$

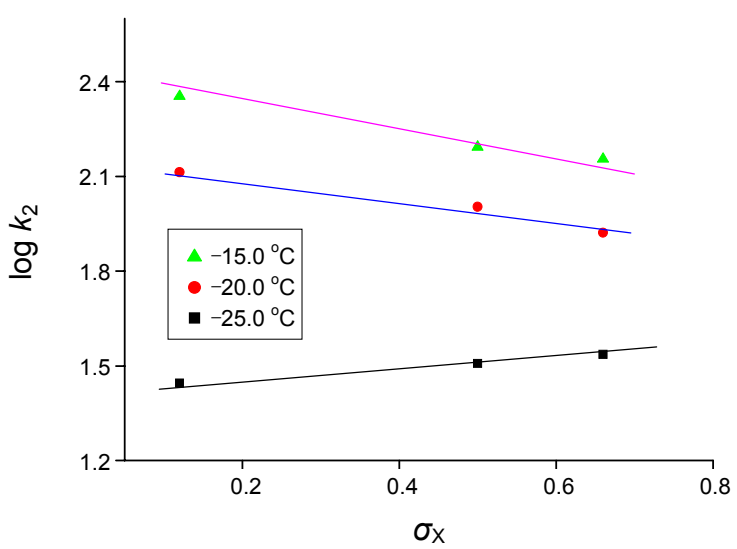

Figure 4. The Hammett $\left(\log k_{2} v s \sigma_{\mathrm{X}}\right)$ plots of the reactions of 10 $\left[\mathrm{Me}_{2} \mathrm{P}(=\mathrm{O}) \mathrm{Cl}\right]$ with $3-\mathrm{MeO}, 4-\mathrm{Ac}$, and $4-\mathrm{CN}$ pyridines in $\mathrm{MeCN}$ at $-15.0,-20.0$, and $-25.0{ }^{\circ} \mathrm{C}$. The $\rho_{\mathrm{X}}$ values are -0.38 at $-15.0,-0.34$ at -20.0 , and +0.16 at $-25.0{ }^{\circ} \mathrm{C}$.

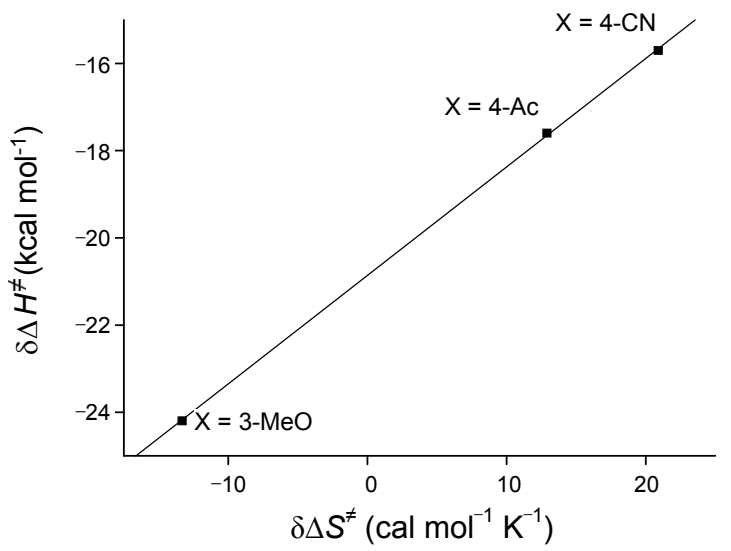

Figure 5. Isokinetic relationship of the reactions of $10\left[\mathrm{Me}_{2} \mathrm{P}(=\mathrm{O}) \mathrm{Cl}\right]$ with 3-MeO, 4-Ac, and 4-CN pyridines in $\mathrm{MeCN}$ resulting in isokinetic temperature (slope), $T_{\text {ISOKINETIC }}=249.4{ }^{\circ} \mathrm{K}=-23.8^{\circ} \mathrm{C}$. 
3-MeO; $\Delta H^{\neq}=19.6$ and $\Delta S^{\neq}=-28$ for $\mathrm{X}=4$-Ac; $\Delta H^{\neq}=17.7$ $\mathrm{kcal} / \mathrm{mole}$ and $\Delta S^{\ddagger}=-20$ eu for $\mathrm{X}=4-\mathrm{CN}$.

$\delta \Delta G^{\neq}=\delta \Delta H^{\neq}-T \delta \Delta S^{\ddagger}=0$ when $\delta \Delta H^{\neq}=T_{\text {ISOKINETIC }} \delta \Delta S^{\ddagger}$

In summary, the pyridinolyses of dimethyl phosphinic (10) and thiophosphinic chlorides (1S) are studied kinetically in $\mathrm{MeCN}$ at -25.0 and $35.0{ }^{\circ} \mathrm{C}$, respectively. Both reactions proceed through concerted mechanism, and exhibit biphasic concave upward free energy relationships due to a change of nucleophilic attacking direction. The unusual positive $\rho_{\mathrm{X}}$ and negative $\beta_{\mathrm{X}}$ values of $\mathbf{1 0}$ for the weakly basic pyridines are ascribed to isokinetic relationship.

\section{Experimental Section}

Materals. GR grade dimethyl phosphinic (10) $(\min 97 \%)$ and thiophosphinic (1S) chlorides (min. 98\%), were used without further purification. GR grade pyridines were used without further purification. HPLC grade acetonitrile (less than $0.005 \%$ water content) was used without further purification.

Kinetic measurements. Conductometric rate measurements were carried out using self-made computer-aided automatic A/D converter conductivity bridges. The pseudo-first-order rate constants $\left(k_{\text {obsd }}\right)$ were determined as previously described ${ }^{\text {la-h }}$ using large excesses of nucleophiles, $[\mathbf{1 0}]=0.001 \mathrm{M}$ and $\left[\mathrm{XC}_{5} \mathrm{H}_{4} \mathrm{~N}\right]=$ $0.01-0.022 \mathrm{M} ;[\mathbf{1 S}]=0.001 \mathrm{M}$ and $\left[\mathrm{XC}_{5} \mathrm{H}_{4} \mathrm{~N}\right]=0.01-0.05 \mathrm{M}$. Each pseudo-first-order rate constants value $\left(k_{\text {obsd }}\right)$ was averaged obtained from more than three runs, which were reproducible within $\pm 3 \%$.

Product analysis. Dimethyl phosphinic (at $-25.0{ }^{\circ} \mathrm{C}$ ) and thiophosphinic (at $35.0^{\circ} \mathrm{C}$ ) chlorides were reacted with excess pyridine for more than 15 half-lives in acetonitrile, as previously described. ${ }^{1 f, g}$ The insoluble products were washed several times with diethyl ether and isolated. The solvent was removed under reduced pressure. Analytical data of the products gave the following results:

$\left(\mathbf{C H}_{3}\right)_{\mathbf{2}} \mathbf{P}(=\mathbf{O}) \mathbf{N}^{+} \mathbf{C}_{5} \mathbf{H}_{5} \mathbf{C l}^{-}$: Dark yellow liquid; ${ }^{1} \mathrm{H}$ NMR (400 $\left.\mathrm{MHz}, \mathrm{CDCl}_{3}\right) \delta 1.44,1.45,1.46,1.47,1.48,1.49,1.51,1.52$ $\left(6 \mathrm{H}, \mathrm{m}, \mathrm{CH}_{3}\right), 7.21,7.23,7.24,7.95,7.96,7.97,8.41,8.41,8.42$, $8.43,8.89$ (5H, m, pyridine); ${ }^{13} \mathrm{C}$ NMR $\left(100 \mathrm{MHz} \mathrm{CDCl}_{3}\right) \delta$ $16.16\left(\mathrm{CH}_{3}\right), 17.12\left(\mathrm{CH}_{3}\right), 127.04,141.41,145.352,149.09$ $(\mathrm{C}=\mathrm{C}$, pyridine $) ;{ }^{31} \mathrm{P}$ NMR $\left(162 \mathrm{MHz}, \mathrm{CDCl}_{3}\right) \delta 59.33(1 \mathrm{P}, \mathrm{s}$, $\mathrm{P}=\mathrm{O}) ; \mathrm{m} / z, 156\left(\mathrm{M}^{+}\right)$; Anal. Calcd for $\mathrm{C}_{7} \mathrm{H}_{11} \mathrm{ClNOP}$ : C, 43.9; H, 5.8; N, 7.3. Found: C, 44.2; H, 5.7; N, 7.4.

$\left(\mathbf{C H}_{3}\right)_{2} \mathbf{P}(=\mathbf{S}) \mathbf{N}^{+} \mathbf{C}_{5} \mathbf{H}_{5} \mathbf{C l}^{-}$: White solid; $\mathrm{mp} 98-100{ }^{\circ} \mathrm{C} ;{ }^{1} \mathrm{H}$ NMR $\left(400 \mathrm{MHz}, \mathrm{CDCl}_{3}\right) \delta 2.05,2.06,2.07,2.08,2.09(6 \mathrm{H}, \mathrm{m}$, $\left.\mathrm{CH}_{3}\right), 7.98,8.00,8.02,8.05,8.88,8.89(5 \mathrm{H}, \mathrm{m}$, pyridine $) ;{ }^{13} \mathrm{C}$ NMR $\left(100 \mathrm{MHz}, \mathrm{CDCl}_{3}\right) \delta 25.75,\left(\mathrm{CH}_{3}\right), 26.48\left(\mathrm{CH}_{3}\right), 127.10$, 141.05, $145.57\left(\mathrm{C}=\mathrm{C}\right.$, pyridine); ${ }^{31} \mathrm{P}$ NMR $\left(162 \mathrm{MHz}, \mathrm{CDCl}_{3}\right)$ $\delta 98.59(1 \mathrm{P}, \mathrm{s}, \mathrm{P}=\mathrm{S}) ; \mathrm{m} / z, 172\left(\mathrm{M}^{+}\right)$(HRMS).

Acknowledgments. This work was supported by Inha University Research Grant.

\section{References}

1. Pyridinolysis: (a) Guha, A. K.; Lee, H. W.; Lee, I. J. Org. Chem. 2000, 65, 12. (b) Lee, H. W.; Guha, A. K.; Kim, C. K.; Lee, I. J. Org. Chem. 2002, 67, 2215. (c) Adhikary, K. K.; Lee, H. W.; Lee, I. Bull. Korean Chem. Soc. 2003, 24, 1135. (d) Hoque, M. E. U.; Dey, N. K.; Guha, A. K.; Kim, C. K.; Lee, B. S.; Lee, H. W. Bull. Korean Chem. Soc. 2007, 28, 1797. (e) Adhikary, K. K.; Lumbiny, B. J.; Kim, C. K.; Lee, H. W. Bull. Korean Chem. Soc. 2008, 29 , 851. (f) Lumbiny, B. J.; Adhikary, K. K.; Lee, B. S.; Lee, H. W. Bull. Korean Chem. Soc. 2008, 29, 1769. (g) Dey, N. K.; Hoque, M. E. U.; Kim, C. K.; Lee, H. W. J. Phys. Org. Chem. 2010, 23, 1022. (h) Guha, A. K.; Kim, C. K.; Lee, H. W. J. Phys. Org. Chem. DOI. 10.1002/poc.1788. Anilinolysis: (i) Guha, A. K.; Lee, H. W.; Lee, I. J. Chem. Soc., Perkin Trans. 2 1999, 765. (j) Lee, H. W.; Guha, A. K.; Lee, I. Int. J. Chem. Kinet. 2002, 34, 632. (k) Hoque, M. E. U.; Dey, S.; Guha, A. K.; Kim, C. K.; Lee, B. S.; Lee, H. W. J. Org. Chem. 2007, 72, 5493. (1) Hoque, M. E. U.; Lee, H. W. Bull. Korean Chem. Soc. 2007, 28, 936. (m) Dey, N. K.; Han, I. S.; Lee, H. W. Bull. Korean Chem. Soc. 2007, 28, 2003. (n) Hoque, M. E. U.; Dey, N. K.; Kim, C. K.; Lee, B. S.; Lee, H. W. Org. Biomol. Chem. 2007, 5, 3944. (o) Dey, N. K.; Hoque, M. E. U.; Kim, C. K.; Lee, B. S.; Lee, H. W. J. Phys. Org. Chem. 2008, 21, 544. (p) Lumbiny, B. J.; Lee, H. W. Bull. Korean Chem. Soc. 2008, 29, 2065. (q) Dey, N. K.; Hoque, M. E. U.; Kim, C. K.; Lee, B. S.; Lee, H. W. J. Phys. Org. Chem. 2009, 22, 425. (r) Dey, N. K.; Kim, C. K.; Lee, H. W. Bull. Korean Chem. Soc. 2009, 30, 975. (s) Hoque, M. E. U.; Guha, A. K.; Kim, C. K.; Lee, B. S.; Lee, H. W. Org. Biomol. Chem. 2009, 7, 2919. (t) Dey, N. K.; Lee, H. W. Bull. Korean Chem. Soc. 2010, 31, 1403. (u) Dey, N. K.; Kim, C. K.; Lee, H. W. Org. Biomol. Chem. DOI. 10.1039/c0ob00517g. Theoretical: (v) Lee, I.; Kim, C. K.; Li, H. G.; Sohn, C. K.; Kim, C. K.; Lee, H. W.; Lee, B. S. J. Am. Chem. Soc. 2000, 122, 11162.

2. (a) Lee, I.; Kim, C. K.; Han, I. S.; Lee, H. W.; Kim, W. K.; Kim, Y. B. J. Phys. Chem. B 1999, 103, 7302. (b) Coetzee, J. F. Prog. Phys. Org. Chem. 1967, 4, 45.

3. (a) Hondal, R. J.; Bruzik, K. S.; Zhao, Z.; Tsai, M. D. J. Am. Chem. Soc. 1997, 119, 5477. (b) Holtz, K. M.; Catrina, I. E.; Hengge, A. C.; Kantrowitz, E. R. Biochemistry 2000, 39, 9451. (c) Omakor, J. E.; Onyido, I.; vanLoon, G. W.; Buncel, E. J. Chem. Soc., Perkin Trans. 2 2001, 324. (d) Gregersen, B. A.; Lopez, X.; York, D. M. J. Am. Chem. Soc. 2003, 125, 7178. (e) Onyido, I.; Swierczek, K.; Purcell, J.; Hengge, A. C. J. Am. Chem. Soc. 2005, 127, 7703. 324. (f) Liu, Y.; Gregersen, B. A.; Hengge, A. C.; York, D. M. Biochemistry 2006, 45, 10043.

4. Hehre, W. J.; Random, L.; Schleyer, P. V. R.; Pople, J. A. Ab Initio Molecular Orbital Theory; Wiley: New York, 1986; Chapter 4.

5. Charton, M. Prog. Phys. Org. Chem. 1987, 16, 287.

6. Taft, R. W. Steric Effect in Organic Chemistry, ed. Newman, M. S.; Wiley: New York, 1956; Chapter 3.

7. (a) Jencks, W. P.; Brant, S. R.; Gandler, J. R.; Fendrich, G.; Nakamura, C. J. Am. Chem. Soc. 1982, 104, 7045. (b) Onyido, I.; Swierczek, K.; Purcell, J.; Hengge, A. C. J. Am. Chem. Soc. 2005, 127,7703 .

8. Lee, I.; Lee, W. H.; Lee, H. W.; Bentley, T. W. J. Chem. Soc., Perkin Trans. 2 1993, 141.

9. Chang, S.; Koh, H. J.; Lee, B. S.; Lee, I. J. Org. Chem. 1995, 60, 7760 .

10. Jencks, W. P. Chem. Rev. 1985, 85, 511.

11. (a) Bernasconi, C. F. Acc. Chem. Res. 1987, 20, 301. (b) Bernasconi, C. F. Adv. Phys. Org. Chem. 1992, 27, 119.

12. Gilliom, R. D. Introduction to Physical Organic Chemistry; Addison-Wesley; Philippines, 1970; pp 167-169. 